Микола ГАЛІВ,

orcid.org/ 0000-0001-7068-3124

кандидат педагогічних наук, дочент кафедри історії України Дрогобицького державного педагогічного університету імені Івана Франка (Дрогобич, Україна) halivm@yahoo.com

Анна ОГАР,

orcid.org/ 0000-0002-4917-8008

кандидат філологічних наук, старший викладач кафедри філологічних дисциплін та методики їх викладання у початковій школі Дрогобииького державного педагогічного університету імені Івана Франка (Дрогобич, Україна) annaogar@ukr.net

\title{
ПОЛЬСЬКІ ПРОФЕСІЙНІ ШКОЛИ НА ДРОГОБИЧЧИНІ У РОКИ НАЦИСТСЬКОЇ ОКУПАЦІї (1941 - 1944)*
}

У статті розкрито становище польського професійного шкільництва на Дрогобиччині у 1941 - 1944 р. На основі документів німецьких окупаційних органів управління освітою показано формування трьох основних груп фахових шкіл: промислово-ремісничої, торгівельної, сільськогосподарської. Дослідження охоплює територію Дрогобицької області УРСР, яка під час німецької окупації була розподілена між Галицьким і Краківським дистриктами Генеральної Губернії.

Ключові слова: польські професійні школи, Дрогобицька область, нацистська окупація.

Лim. 26.

Mykola HALIV,

Ph D (Education), Associate Professor of the Department of History of Ukraine, Drohobych Ivan Franko State Pedagogical University (Ukraine,Drohobych)halivm@yahoo.com

Anna OHAR, Ph D (Philology), Senior lecturer of the Department of Philological Sciences and Techniques of Teaching in Elementary School, Drohobych Ivan Franko State Pedagogical University (Drohobych,Ukraine) annaogar@ukr.net

\section{POLISH VOCATIONAL SCHOOLS IN DROHOBYCH REGION DURING THE YEARS OF NAZI OCCUPATION (1941 - 1944)}

In the article the state of Polish vocational schooling on the territory of Drohobych region in 1941 - 1944 is characterized. On the basis of documents of the occupational education governing bodies the formation of three basic groups of vocational schools is shown, - respectively, of handicraft industry, trade, and agriculture. The dynamics of number of pupils and teaching personnel structure of the establishments of vocational training are analyzed. The content of curricula of some schools and their material maintenance is clarified. The research covers the territory of the former Drohobych region of Ukrainian SSR which during the German occupation was distributed between Galician and Krakow districts of the General Gubernia.

The author concludes that Polish vocational schooling in Drohobych region under German occupation by far did not surpass Ukrainian by the number of establishments, teachers and pupils. However, both Polish and Ukrainian vocational institutions shared not only the conditions of functioning, particularly, the occupational policy in education, but also the failure to meet the popular requirements (insufficient number of establishments for a percentage indicator of population), bad material maintenance, gradual reduction of the pupils contingent. The author underlines that the existence of separate Ukrainian and Polish schools was conductive to strengthening of the national estrangement of Ukrainians and Poles, leading to transformation of educational institutions into ethnically limited, cultural and ideologically closed centres.

Key words: Polish vocational schools, Drohobych region, Nazi occupation.

Ref. 26.

* Публікація містить результати досліджень, проведених у рамках виконання наукового проекту «Українсько-польсько-єврейські взаємини у Східній Галичині (перша половина XX ст.): історичний досвід, уроки для сучасності», що фінансується за рахунок коштів загального фонду Державного бюджету. ID:95861 29.08.2017 (176-1). 
Николай ГАЛИВ,

кандидат педагогических наук, дочент, доцент кафедры истории Украиньл Дрогобычского государственного педагогического университета имени Ивана Франко (Украина, Дрогобыч) halivm@yahoo.com

Анна ОГАР,

кандидат филологических наук, старший преподаватель кафедры филологических дисциилин и методики их преподавания в начальной школе Дрогобычского государственного педагогического университета имени Ивана Франко (Украина, Дрогобыч) annaogar@ukr.net

\section{ПОЛЬСКИЕ ПРОФЕССИОНАЛЬНЫЕ ШКОЛЫ НА ДРОГОБЫЧЧИНЕ В ГОДЫ НАЦИСТСКОЙ ОККУПАЦИИ (1941 - 1944)}

В статье раскрыто положение польского профессионального школ на Дрогобиччини в $1941-1944$ г. На основе документов немецких оккупационных органов управления образованием показано формирование трех основных групп профессиональных школ: промышленно-ремесленной, торговой, сельскохозяйственной. Исследование охватывает территорию Дрогобычской области УССР, которая во время немецкой оккупации была распределена между Галицким и Краковским дистриктами Генеральной Губернии.

Ключевые слова: польские профессиональные школь, Дрогобычский область, начистская оккупация.

Лит. 26.

Постановка проблеми. Стан освіти та рівень культурного життя різних етнічних груп нашого краю в умовах нацистської окупації й досі залишається недостатньо вивченим. Безумовно, на сьогодні значно більше досліджене українське культурне (у тому числі й освітнє) життя східногалицьких земель, натомість становище освіти поляків потребує детальнішої уваги. Зазначена проблема актуалізується не лише наявними історіографічними лакунами, але й суспільно-політичними чинниками: поляки до 1944 - 1946 рр. були значним за чисельністю сегментом населення східногалицьких міст, зокрема й Дрогобича, формували певну частину культурного обличчя Східної Галичини, а сучасні українсько-польські міждержавні взаємини підштовхують до адекватної характеристики ролі «польського чинника» в історії краю, у тому числі й Дрогобиччини періоду нацистської окупації.

Аналіз останніх досліджень. Окремі аспекти становища польського професійного шкільництва на Дрогобиччині висвітлені у працях Г. Стефанюк [14], М. Галіва [5]. У працях польських учених Г. Грицюка [17], Й. Красуського [19], Є. Круля [20], П. Маєвського [21], П. Матусяка [22], С. Медуцького [23], Й. Свєбоди [26], на основі багатого статистичного матеріалу окреслено стан освіти поляків як офіційний, так і підпільний («таємне навчання»), у Генеральній Губерній, зокрема Галичині. Проте Дрогобиччині у працях польських колег увага майже не присвячується.

Мета статті - висвітлити становище польського професійного (фахового) шкільництва на теренах Дрогобиччини у 1941 - 1944 рр. Зауважимо, що географічні межі дослідження охоплюють територію так званої Дрогобицької області УРСР, яка під час німецької окупації була розподілена між галицьким (Дрогобицька, Стрийська, Самбірська округи, частина округи Львів-повіт) та краківським (частина Перемишльської округи з містами Добромиль і Хирів) дистриктами Генеральної Губернії (далі - ГГ).

Виклад основного матеріалу. Ділянці фахової освіти в ГГ приділялася найбільша увага. Як відзначає Н. Антонюк, профосвіта була введена у ранг державної політики з декількох причин. Пріоритетний розвиток фахового шкільництва обумовлювався вимогами освітньої політики німців, яка передбачала забезпечення населення окупованих земель тільки початковою і професійною освітою. 3 іншого боку, на теренах ГГ дуже гостро відчувалася нестача кваліфікованих працівників у різних сферах господарського життя (особливо в кооперації, з якої вибули євреї). Насамперед це стосувалося українців, які до війни практично не мали змоги здобувати професійну освіту $[1,47]$. Брак робітників, у тому числі з фаховою освітою, спостерігався й у Німеччині. Тож учні та випускники фахових шкіл вважалися вагомим ресурсом для поповнення «вакансій» на ринку праці Третього рейху і ГГ.

Професійне шкільництво в ГГ мало такі ділянки: промислово-ремісничу, торгівельну, сільськогосподарську. Крім того, діяли й спеціальні школи мистецького і педагогічного характеру. У кожній ділянці організовувалися три основні типи шкіл: обов'язкові (призначені винятково для 
підвищення професійної кваліфікації й рівня фахової освіти молоді, яка працювала на промислових, ремісничих, торгівельних підприємствах та у сільському господарстві), званеві, фахові (власне середнього ступеня). У них окремо навчалися українці та поляки. Одні з них призначалися для хлопців, інші - для дівчат. Були й коедукаційні заклади. 3 огляду на те, що профшколи мали на меті перспективну спеціалізацію, вони були різноманітними: однорічна фахова торговельна школа зі спеціальними класами для забезпечення та завідування підприємствами, технічні фахові школи для металевого та будівельного промислу, електротехніки, хімтехніки, а також рільничі школи для чоловіків і жінок, музичні школи для мистецького промислу [1, 52-53]. При цьому слід підкреслити, що німецькі середні фахові школи не давали повноцінної середньої освіти, а мали винятково прикладний характер. У них вивчалися тільки ті дисципліни, які були потрібні для розуміння певної «вузької» спеціальності. Наприклад, ветеринарів не вчили літератури, історії або географії, а електриків не навчали біології чи зоології $[13,202]$.

Промислово-ремісничу групу профшкіл на Дрогобиччині започатковано восени 1941 р. Відзначимо, що вона включала державні навчальні заклади двох типів: нижчого - реміснича званева школа з трирічним терміном навчання, та вищого - дворічна фахова промислово-технічна школа. До званевих ремісничих шкіл зазвичай приймалися учні, що закінчили шість класів радянської школи, до фахових технічних - 18-річні особи зі щонайменше закінченими чотирма класами гімназії або ремісничою школою з однорічною фаховою підготовкою. Реміснича школа переважно складалася зі слюсарсько-електричного та електромеханічного відділів (хоча могло бути й більше), а технічна фахова здебільшого включала такі відділи: будови машин і електротехніки, будівництва доріг та мостів, наземного будівництва $[1,53]$.

Більшість ремісничих шкіл все ж були однорічними, належали до обов'язкового рівня й перебували на цілковитому утриманні місцевих підприємств, Українських і Польських комітетів, а отже, трактувалися як приватні. Уже наприкінці 1941 р. у Дрогобичі та Бориславі було відкрито низку ремісничих шкіл для слюсарів, ковалів, електротехніків, шевців, кравців, столярів тощо [1, 54]. На жаль, не можна впевнено стверджувати, скільки з них були званевими, а скільки обов'язковими. Згідно з документами Дрогобицького шульамту (квітень 1942 р.), на терені округи діяли п’ять ремісничих обов'язкових шкіл: три з українською мовою навчання - у Дрогобичі, Бориславі та Східниці, дві з польською - у Дрогобичі та Бориславі (майже усі для хлопців) [6, 3]. Чисельність учнів та викладачів таких освітніх закладів зазвичай не була високою. Так, на 10 квітня 1942 р. в обов'язковій Дрогобицькій ремісничій школі з польською мовою навчання налічувалося 52 учні-хлопці (2 класи) та 5 вчителів [6, 13зв-15].

3 часом, завдяки розгорнутій Польськими окружними комітетами активній пропаганді, кількість учнів, а відтак і викладачів у деяких ремісничих обов'язкових школах поступово зросла. Зокрема, на 22 липня 1942 р. німецькі чиновники Дрогобицької округи зафіксували, що 168 хлопців і 33 дівчат відвідували ремісничі обов'язкові школи з польською мовою навчання [7, 92]. Зауважимо, що в українських ремісничих обов'язкових школах навчалося дещо менше учнів (загалом 173). Уже на початку 1942/43 навч. року у польській ремісничій школі Дрогобича налічувалося 62 учні та 4 вчителі. Бориславські ремісничі школи (українська та польська), з огляду на наявність значної кількості підприємств, були більш чисельними. Зокрема, у польській школі освіту здобували 150 учнів (122 хлопців і 28 дівчат) (4 класи) і працювали 10 вчителів [6, 183-183зв].

Про польські ремісничі школи на інших теренах колишньої Дрогобицької області збереглося небагато інформації. Відомо, що у Самборі діяло дві українські ремісничі званеві школи [9, 6]. Проте припускаємо, що там працювала ще й реміснича званева школа з польською мовою навчання, адже, відповідно до даних Дрогобицького шульамту, станом на 15 вересня 1943 р. у Самбірській окрузі налічувалося три ремісничі (званеві) школи, де працювали 28 викладачів і навчалися 603 учениці, та одна промислово-реміснича (званева) [7, 59, 81]. Однак жодних даних про польську ремісничу званеву школу, як і про ремісничі обов'язкові школи Самбірщини нам віднайти не вдалося. Подібне доводиться констатувати й щодо Стрийської округи. Проте відомо, що ремісничі школи з польською мовою навчання працювали у Добромилі, Хирові, Нижанковичах [26, 187].

На теренах колишньої Дрогобицької області функціонували декілька фахових промислово-технічних шкіл. Однією з них була відкрита 1 - 2 лютого (дозвіл на відкриття від уряду дистрикту 
надійшов 16 березня) 1942 р. на базі електромеханічного технікуму Державна фахова промислово-технічна школа в Дрогобичі. На 1943 р. Дрогобицька технічна школа офіційно вважалася філією «Фахової Технічної Школи у Львові», лише з одним відділом - машино-будівничим. Водночас при ній функціонувала чоловіча трирічна реміснича званева школа зі слюсарсько-механічним та електротехнічним відділами $[2,21 ; 15,5]$. До останньої приймали 14-річних і старшого віку хлопців, які закінчили семикласну народну школу (річна вартість навчання - 100 зл.) [4, 6]. Обидві школи громадянством сприймалися як єдине ціле, що помітно з матеріалів періодичної преси. Дрогобицька технічна школа була навчальним закладом з українською мовою навчання, проте там діяли й відділи для польськомовних учнів [6, 43в]. Керівником школи призначено інженера Дмитра Гижого. Крім нього, на лютий-березень 1942 р. у закладі вчителювали Станіслав Смольницький, Григорій Опалка, інженери Степан Яворський, Георг Стржемський, Кароль Дудзяк, Мстислав Мсцівуєвський, о. Петро Подоляк, о. Леон Телеш, а також інструктори Владислав Боск, Франц Вишинський, Володимир Кушнір, Северин Черевко [6, 5].

Як свідчить звіт дрогобицького крейсшульрату перед керівництвом відділу науки та навчання уряду дистрикту, школа (точніше ії званева частина) протягом першої половини лютого 1942 р. налічувала 136 учнів, з них у першому класі - 93 (66 українців у двох відділах і 27 поляків в одному відділі), у другому - 18 (16 українців і 2 поляків - єдиний відділ), третьому - 25 (23 українці і 2 поляки - єдиний відділ). Однак після відкриття перевідних класів у Дрогобицькій українській державній гімназії частина учнів перейшли туди. Крім того, певна частина учнів першого класу 3 різних причин покинули школу, тож на 1 квітня загальна кількість учнів сягала 117 осіб. При цьому, у квітні відвідували школу всього 79 учнів (у першому класі - 34 українці і 9 поляків, у другому - 20 учнів, у третьому - 16 учнів) [7, 110-110зв]. За даними шульамту, на 12 червня 1944 р. у Дрогобицькій технічній школі працювали 11 вчителів: Дмитро Гижий, Степан Яворський, Омелян Єднакий, Франц Вишенський, Володимир Кушнір, Тадеуш Смольницький, Станіслав Смольницький, Михайлина Ясеницька, Михайло Коцюба, Юліан Кузан, Кароль Гринда [6, 142].

Унікальною за своєю спеціалізацією на теренах дистрикту «Галіція» була бурильнотехнічна фахова школа $з$ польською і українською мовами навчання у Бориславі («школа нафтових вертачів», «свердлярська школа»). Дозвіл на її відкриття уряд дистрикту надав 16 березня 1942 р. На той час там у п’яти класах (трьох польських та двох українських) навчалися 140 учнів [6, 9зв; 7, 92], а вчителювали Йозеф Войнар, Франц Полончик, Богдан Дрималюк, Генріх Горка, Януш Граздіцький, Анна Боркова, Сигізмунд Мусят $[6,10]$. Школа готувала фахівців із трьох спеціальностей: 1) «вертичні асистенти» (трирічний курс навчання), що готував до низової управлінської роботи у сфері нафтовидобутку (приймалися особи з дво-трирічною практикою та освітою на рівні 4 кл. гімназії старого типу чи іншої рівнорядної освіти); 2) »вертачі» (дворічний курс навчання; приймалися 21-річні абітурієнти 3 дволітньою практикою та освітою на рівні 4 кл. народної школи); 3) машиністи та механіки (однорічний курс навчання; приймалися особи з будь-якою початковою освітою та дворічною практикою) $[11,3]$. На початку 1942/43 навч. року ці спеціальності під керівництвом 9 викладачів здобували 158 учнів [6, 183-183зв]. До слова, протягом міжвоєнного періоду у згаданій школі «управителів копалень нафти» не навчався жоден українець $[12,5]$.

Група торговельних шкіл почала формуватися одночасно з ремісничими. Відомо, що званева трирічна торговельна польськомовна школа 3 «великим числом учнів» діяла у правобережному Перемишлі (на вул. Смолки) [24; 26, 187], котрий до нацистської окупації належав до Дрогобицької області.

У Дрогобичі ж 1 лютого 1942 р. розпочало діяльність одразу чотири державні школи цієї групи: торговельна фахова школа з польською мовою навчання, торговельна фахова школа з українською мовою навчання, торговельна званева школа з польською мовою навчання та торговельна званева школа з українською мовою навчання $[6,3 ; 7,112]$. Українські школи очолив Савин Ясеницький, польські - Яніна Стоцька. На початку шкільного року до дрогобицьких торговельних шкіл записалися 199 учнів [7, 112] (приймали 14-літніх осіб із закінченою принаймні чотирикласною народною школою [4, 6]). Однак у квітні 1942 р. залишилося 182 школярі: у Дрогобицькій державній торговельній школі з українською мовою навчання - 100 учнів (2 класи), з них 26 хлопців і 76 дівчат, торговельній фаховій школі з українською мовою навчання - 18 учнів (1 клас, 
6 хлопців і 12 дівчат), польській торговельній званевій школі - 56 учнів (3 класи, з них 13 хлопців і 43 дівчини), польській торговельній фаховій школі - 18 учнів (1 клас, 8 хлопців і 10 дівчат) [6, 5зв, 6зв, 7зв, 8зв]. Згідно зі звітом крейсшульрату, на 15 травня 1942 р. кількість учнів у званевих школах ненабагато зменшилася (97 в українській, 44 в польській), але зросла, знову ж ненабагато, у фахових школах: 19 в українській та 20 у польській (всього - 180 учнів) [7, 112].

Як і в українських, навчальний процес в обидвох польських торгівельних школах здійснював, по суті, один педколектив - Яніна Стоцька, Зигмунд Шнайдер, Мечислав Мсцівуєвський, Казимир Гофман, Станіслава Гофман, Фердинанд Шенянський, Кароль Дудзяк, Ванда Дюк, о. Леон Телеш, 3 тією лишень різницею, що у звичайній торгівельній школі працювала ще й Марія Ясеницька, а у фаховій - Андрій Геврик [6, 8-9]. Майже всі вони ще до 1939 р. працювали у профшколах.

Викладалися у торговельних школах такі предмети: товарознавство, релігія, організація підприємництва, бухгалтерія, основи економіки, правознавство, стенографія і друкування, обчислення (математика), «наука реклами», німецька мова і література $[6,6 ; 22,55]$. Навчання тривало з 8.00 до 13.20. 3 огляду на матеріальну скруту, у школах не вистачало навчальних посібників і підручників, друкарської машинки та паперу, а вчителі уперше отримали заробітну плату лише 6 травня [7, 112]. Середнє урочне навантаження викладача дрогобицьких торговельних шкіл становило 11-12 занять на тиждень. Так, у польській торговельній школи Дрогобича число занять на осінь 1942 р. сягало: керівник Яніна Стецька - 18, о. Леон Телеш - 6, Мстислав Мсцівуєвуєвський - 9, Зигмунт Шнейдер - 12, Ванда Дюк - 14, Кароль Дудзяк - 10, Казимир Гофман - 17 , Станіслава Гофман - 14, Марія Ясеницька - 1 [7, 31].

Тож на початку своєї діяльності в умовах німецької окупації дрогобицькі торговельні школи загалом налічували 199 учнів та 20 вчителів. До літа 1942 р. чисельність учнів цих навчальних закладів дещо знизилася й 22 липня становила 175 осіб (в українській званевій торговельній школі - 96, польській - 43, в обох фахових школах залишилося по 18 учнів) [7, 92]. Зрештою, напередодні 1942/43 навч. року німецькі власті, з огляду на малу наповнюваність, вирішили ліквідувати обидві фахові торговельні школи, залишивши тільки званеві. Власне на початку нового шкільного року в Дрогобичі діяло дві торговельні званеві школи: українська (три класи, 112 учнів, 3 них 28 хлопців і 84 дівчини, 10 вчителів, з них 7 чоловіків і 3 жінки) та польська (три класи, 73 учні, з них 21 хлопець і 52 дівчини, 9 вчителів, з них 5 чоловіків і 4 жінки) [6, 183-183зв]. Припускаємо, що в останній шкільний рік періоду німецької окупації обидві школи вступили уже як єдиний навчальний заклад, але з українськими та польськими класами. У львівській пресі друкувалося оголошення про набір лише до однієї державної торговельної школи в Дрогобичі [4, 6]. Згідно з даними шульамту від 12 червня 1944 р., в єдиній на той час торговельній школі Дрогобича працювали 16 вчителів: Савин Ясеницький (керівник), Марія Ясеницька, о. Петро Подоляк, Мирослав Кравчишин, Йосип Бойко, Яніна Стоцька, Казимир Гофман, Станіслава Гофман, Кароль Дудзяк, Зеновія Ярема, Ванда Дюк, Зигмунд Шнейдер, Мстислав Мсцівуєвський, Ірена Жагаляк, Адріана Попель, Степан Білоган [6, 1413в].

Найбільш широко розбудованою стала ділянка сільськогосподарського шкільництва, організація якого припала на 1942 р. Українське та польське громадянство піклувалися про організацію одно-, дворічного обов'язкового (прилюдного) сільськогосподарського шкільництва. Зауважимо, що на теренах дистрикту «Галіція» для поляків створювалися тільки обов'язкові сільськогосподарські школи. На кінець грудня 1942 р. у галицькому дистрикті налічувалося 175 польських обов'язкових сільськогосподарських шкіл, де працювали 760 викладачів, навчаючи 10300 учнів [20, 152]. Згідно з розпорядженням німецьких властей, кожну обов'язкову сільськогосподарську школу мали відвідувати 180 - 300 підлітків. Передбачалося, що учні можуть ходити до школи один раз на тиждень групами по 30 - 50 осіб, а вчителі зобов'язані були кожного дня займатися з іншою групою $[8,20]$.

Крім дозволених обов'язкових рільничих шкіл, німецькою владою було організовано два типи званевих сільськогосподарських навчальних закладів: 1) однорічні рільничі школи для хлопців і дівчат, однорічні городницькі та господинські школи (обов'язкові для всієї сільської молоді); 2) дворічні чоловічі рільничі школи, дворічні дівочі господинські школи, дворічні городницькі школи (останні діяли у Львові). До однорічної рільничої школи приймалися 16-річні юнаки та юнки, що закінчили народну школу та мали дворічну практику в сільському господарстві. Для вступу до 
однорічної городничої школи потрібні були такі ж вік і освіта, але трирічна сільськогосподарська практика або закінчення рільничої школи. На перший навчальний рік дворічної чоловічої рільничої школи приймалися 18-річні абітурієнти з освітою на рівні 8-го класу радянської школи, 4-го класу гімназії нового типу (6-го класу гімназії старого типу) або трирічної профшколи, а також однорічною практикою в сільському господарстві. На другий рік цієї ж школи приймалися 19-річні юнаки 3 аналогічним рівнем освіти, однак дворічною практикою на господарстві. Подібні вимоги ставили й до тих, хто бажали навчатися у дворічній жіночій господинській школі. Звісно, головною умовою прийняття до всіх цих шкіл були успішно складені вступні іспити з німецької мови, рахунків, природи, а також української або польської мов. До цих шкіл також брали випускників і студентів I-II курсів радянських сільськогосподарських шкіл і зоотехнікумів. Зголошення на вступ слід було подавати також у відділ науки і навчання уряду дистрикту Галичина $[3,4 ; 10,2]$.

Однорічні школи поділялися за типами: сільськогосподарські для хлопців і дівчат, школи домашнього господарства, городничо-садівничі, молочарські, лісові. Закінчення такого навчального закладу дозволяло стати управителем середнього господарства чи сільської господарки, після неї можна вступати до дворічної школи, що за рівнем відповідала деяким ліцеям. Закінчення ж останньої давало змогу працювати волосним агрономом, управителем середнього сільського господарства, а після закінчення педагогічного курсу - вчителем сільськогосподарської школи $[1,55]$.

Обов'язкові сільськогосподарські школи, звісно, були найбільш чисельними, оскільки створювалися майже у кожній волосній громаді. Учні-поляки змушені були відвідувати українські школи. Зокрема, відомо, що поляки Стрийщини навчалися у відомих в окрузі та за ії межами школах у Черниці та Бережниці. Для вступу до цих шкіл полякам слід було скласти вступний іспит 3 німецької і польської мов, арифметики і природознавства $[8,2]$.

У Дрогобицькій окрузі створення сільськогосподарських шкіл, передовсім обов'язкових, розпочалося на початку 1942 р. Згідно із даними шульамту, на 13 травня 1942 р. у селах округи працювало 20 шкіл, з них дві польські - у Меденичах і Рихтичах [6, 41]. Причому, якщо у Меденичах поряд 3 польською діяла «конкуруюча» українська школа, то в Рихтичах лише польська. Уже на початку 1942/43 навч. року кількість обов'язкових сільськогосподарських шкіл на теренах округи Дрогобич зменшилася до 16-ти, зокрема закрилася українська школа в Меденичах, де залишилася лише польська. Усі вони вважалися приватними, оскільки перебували під опікою Українського та Польського комітетів. Рихтицька польська обов'язкова сільськогосподарська школа була однією 3 найбільших (5 класів, 219 учнів і 8 вчителів), хоча й поступалася українським школам в Літині та Орові, де число учнів перевищувало три сотні осіб. Загалом, у сільськогосподарських обов'язкових школах Дрогобицької округи в жовтні - листопаді 1942 р. навчалися 2545 учнів, з них в українських - 2238, польських - 307. Відповідно, працювали 117 вчителів (103 в українських, 14 у польських) [6, 183-183зв]. Тож на одного вчителя в цих школах припадало 21,7 учня.

Поширеною ланкою сільськогосподарського шкільництва були господинські (школи домашніх господинь). Деякі з них діяли у Стрию, Перемишлі, Добромилі, але детальну інформацію маємо лише про дві господинські школи (українську та польську) у Дрогобичі, які виникли на початку 1942 р. На чолі Державної школи домашнього господарства з українською мовою навчання перебувала Гелена Валігура. На квітень 1942 р. там учителювали о. Атанасій Кот, Олексій Кунцяк, Орест Полянський, Георгій Опалко, Юлія Савка, Павліна Данилович [6, 1]. Згідно з матеріалами шульамту, 22 липня 1942 р. у школі здобувало освіту всього 25 дівчат [7, 92]. Державна школа домашнього господарства 3 польською мовою навчання налічувала спочатку 27 учениць та 6 вчителів [6, 12зв-13]. Проте вже в липні 1942 р. кількість учнів зменшилася до 22 [7, 92].

На початку 1942/43 навч. року українська господинська школа в Дрогобичі дещо зросла у плані учнівського контингенту - 50 дівчат під керівництвом 4 вчителів здобували господарську освіту (щоправда, за матеріалами газети «Голос Підкарпаття,» восени 1942 р. вона налічувала 120 учениць $[16,6])$. Водночас у польській школі навчалися лише 27 дівчат, проте працювали 6 викладачів [6, 183-1833в]. На жаль, джерела «замовчують» число учнів у школах протягом 1943 - 1944 рр., однак припускаємо, що воно поступово збільшувалося, оскільки зростав педагогічний колектив кожної школи. Так, за даними шульамту на 12 червня 1944 р., у польській школі домашнього господарства 
працювали 8 вчителів (Марія Скиба, Збігнєв Корон, Ванда Новак, Ольга Смольницька, Вікторія Томчик, Михайлина Сольчак, Антоніна Зашкевич, Ельжбета Кресаків) [6, 141].

На цьому й вичерпується перелік польського професійного шкільництва Дрогобицької області УРСР у роки нацистської окупації. Як відомо, уряд ГГ відкривав в Галичині учительські семінарії лише з українською мовою навчання (зокрема в Самборі), тож поляки, на відміну від українців, не отримали можливості готувати педагогічні кадри для власного початкового шкільництва.

Висновки. Отже, польське фахове шкільництво на теренах окупованої Дрогобицької області за кількісним складом інституцій, учителів та учнів, звісно, поступалося українському. Одначе 3 українськими освітніми інституціями фахового спрямування його поєднували не лише умови існування, зокрема окупаційна політика в освітній сфері, але й невідповідність запитам населення (недостатня кількість закладів на відсотковий показник мешканців), погане матеріальне забезпечення, поступове падіння контингенту учнів. Наголосимо й на тому, що існування окремих українських і польських шкіл, сприяло посиленню національної відчуженості між українцями і поляками та призводило до перетворення закладів освіти на етнічно обмежені, культурно та ідеологічно замкнуті осередки.

\section{СПИСОК ВИКОРИСТАНИХ ДЖЕРЕЛ І ЛІТЕРАТУРИ}

1. Антонюк Н. В. Українське культурне життя в Генеральній Губернії (1939 - 1944 роки) / Н. В. Антонюк. - Львів, Б. в., 1997. - 232 с.

2. Вісник Українського Центрального Комітету. - 1942. - Ч. 6/32. - 15 червня. - С. 21.

3. Вписи до с.-господарських шкіл // Львівські вісті. - 1942. - Ч. 3(127). - 4/5 січня. - С. 4.

4. Вписи до фахових шкіл в Дрогобичі // Голос Підкарпаття. - 1943. - Ч. 27. - 4 липня. - С. 6.

5. Галів М. Між серпомолотом і свастикою: освіта на Дрогобиччині у 1939 - 1944 pp. / Микола Галів. - Дрогобич: ПП «Коло», 2010 - 337 с.

6. Державний архів Львівської області (далі - ДАЛО). - Ф. Р-1926. - Оп. 1. - Спр. 2.

7. ДАЛО. - Ф. Р-1926. - Оп. 1. - Спр. 90.

8. ДАЛО. - Ф. Р-1964. - Оп. 1. - Спр. 10.

9. 3 українського життя. Самбірщина [Професійні школи] // Краківські вісті. - 1943. - Ч. 216(954). 29 вересня. - С. 6.

10. Заснування двох рільничих шкіл // Стрийські вісті. - 1942. - № 2. -7 січня. - С. 2.

11. Ів. О-ич. Школа нафтових вертачів у Бориславі / Ів. О-ич // Вільне слово. - 1942. - № 7 (81). - 17 січня. - С. 3.

12. Нові управителі копалень нафти // Краківські вісті. - 1943. - Ч. 293(1031). - 29 грудня. - С. 5.

13. Патриляк І. К. Україна в роки Другої світової війни: спроба нового концептуального погляду / І. К. Патриляк, М. А. Боровик. - Ніжин: Видавець ПП Лисенко М.М., 2010. - 590 с.

14. Стефанюк Г. В. Шкільництво в Західній Україні під час німецької окупації (1941 - 1944 рр.)/ Г. В. Стефанюк: Дис... канд. іст. наук: 07.00.01. - Івано-Франківськ, 2004. - 215 с.

15. Українські професійні школи в Генеральній Губернії // Краківські вісті. - 1943. - Ч. 156(894). 21 липня. - С. 5.

16. Ш Шола дитячих піклувальниць у Дрогобичі // Голос Підкарпаття. - 1942. - Ч. 6. - 4 жовтня. - С. 6.

17. Hryciuk G. Polacy w Maiopolsce Wshodniej wobec okupacji niemieckiej. Przyczynek do prób wprowadzenia «elastycznego kursu» w Dystrykcie Galicji w latach 1943 - 1944 / G. Hryciuk // Acta Universitatis Wratislaviensis: Historia, CXVI: Polska - Kresy - Polacy. Studia Historyczne. - Wrociaw: Wydawnictwo Uniwersytetu Wrociawskiego, 1994. - S. 307-316.

18. Janowski M. Szkolnictwo zawodowe w Przemyślu pod okupacją niemiecką w latach 1940 - 1944 w świetle zasobu Archiwum Państwowego w Przemyślu / M. Janowski // 2003. - T. 17. - S. 111-120.

19. Krasuski J. Tajne szkolnictwo polskie w okresie okupacji hitlerowskiej 1939 - 1945 / J. Krasuski. - Wydanie drugie, rozszerone. - Warszawa: Państwowe Wydawnictwo Naukowe, 1977. - 411 s.

20. Król E. C. Polityka hitlerowska wobec szkolnictwa polskiego na terenie Generalnej guberni (1939 - 1945) / E. C. Król. - Warszawa: Wydawnictwa Szkolne i Pedagogiczne, 1979. - 243 s.

21. Majewski P. Wojna i kultura: instytucje kultury polskiej w okupacyjnych realiach Generalnego Gubernatorstwa 1939 - 1945 / P. Majewski. - Warszawa: Trio, 2005. - $431 \mathrm{~s}$.

22. Matusak P. Edukacja i kultura Polski Podziemnej 1939 - 1945 / P. Matusak. - Siedlce, 1997. - 562 s.

23. Meducki S. Niemieckie okupacyjne szkolnictwo zawodowe w Generalnym Gubernatorstwie 1939- 1945 (na przykładzie dystryktu radomskiego) / Stanisław Meducki // Prace Naukowe Akademi i im. Jana Długosza w Częstochowie. Seria: Pedagogika. - 2012. - T. XXI. - S. 405-411. 
24. Okupacja niemiecka cz. 3: Przemyśl w czasie II wojny światowej. - [Електронний pecypc]. - Режим доступу: http://wojnawp.republika.pl/niemcy/nn3.html

25. Opłaty w szkołach przysposobienia zawodowego // Gazeta Lwowska. Dziennik dla Dystryktu Galicyjskiego. - 1942. - Nr. 20. -24 stycznia. - S. 3.

26. Świeboda J. Zarys historii tajnej oświaty w latach ocupacji hitlerowskiej w powiecie przemyskim / J. Świeboda // Rocznik komisji nauk pedagogicznych PAN. - 1976. - T. XI: Materiały do dziejów oświaty w okresie ocupacji hitlerowskiej (1939 - 1945) na terenie podziemnego okręgu szkolnego krakowskiego. - Cz. X. S. 183-193.

\section{REFERENCES}

1. Antoniuk N. V. Ukrainske kulturne zhyttia v Heneralnii Hubernii (1939 - 1944 roky) / N. V. Antoniuk. Lviv, B. v., 1997. - 232 s.

2. Visnyk Ukrainskoho Tsentralnoho Komitetu. - 1942. - Ch. 6/32. - 15 chervnia. - S. 21.

3. Vpysy do s.-hospodarskykh shkil // Lvivski visti. - 1942. - Ch. 3(127). - 4/5 sichnia. - S. 4.

4. Vpysy do fakhovykh shkil v Drohobychi // Holos Pidkarpattia. - 1943. - Ch. 27. - 4 lypnia. - S. 6.

5. Haliv M. Mizh serpomolotom i svastykoiu: osvita na Drohobychchyni u 1939 - 1944 rr. / Mykola Haliv. Drohobych: PP «Kolo», 2010 - 337 s.

6. Derzhavnyi arkhiv Lvivskoi oblasti (dali-DALO). - F. R-1926. - Op. 1. - Spr. 2.

7. DALO. - F. R-1926. - Op. 1. - Spr. 90.

8. DALO. - F. R-1964. - Op. 1. - Spr. 10.

9. Z ukrainskoho zhyttia. Sambirshchyna [Profesiini shkoly] // Krakivski visti. - 1943. - Ch. 216(954). 29 veresnia. - S. 6.

10. Zasnuvannia dvokh rilnychykh shkil // Stryiski visti. - 1942. - № 2. - 7 sichnia. - S. 2.

11. Iv. O-ych. Shkola naftovykh vertachiv u Boryslavi / Iv. O-ych // Vilne slovo. - 1942. - № 7 (81). 17 sichnia. - S. 3.

12. Novi upravyteli kopalen nafty // Krakivski visti. - 1943. - Ch. 293(1031). - 29 hrudnia. - S. 5.

13. Patryliak I. K. Ukraina v roky Druhoi svitovoi viiny: sproba novoho kontseptualnoho pohliadu / I. K. Patryliak, M. A. Borovyk. - Nizhyn: Vydavets PP Lysenko M.M., 2010. - 590 s.

14. Stefaniuk H. V. Shkilnytstvo v Zakhidnii Ukraini pid chas nimetskoi okupatsii (1941 - 1944 rr.) / H. V. Stefaniuk: Dys... kand. ist. nauk: 07.00.01. - Ivano-Frankivsk, 2004. - 215 s.

15. Ukrainski profesiini shkoly v Heneralnii Hubernii // Krakivski visti. - 1943. - Ch. 156(894). - 21 lypnia. - S. 5.

16. Shkola dytiachykh pikluvalnyts u Drohobychi // Holos Pidkarpattia. - 1942. - Ch. 6. - 4 zhovtnia. - S. 6.

17. Hryciuk G. Polacy w Małopolsce Wshodniej wobec okupacji niemieckiej. Przyczynek do prób wprowadzenia «elastycznego kursu» w Dystrykcie Galicji w latach 1943 - 1944 / G. Hryciuk // Acta Universitatis Wratislaviensis: Historia, CXVI: Polska - Kresy - Polacy. Studia Historyczne. - Wrociaw: Wydawnictwo Uniwersytetu Wrociawskiego, 1994. - S. 307-316.

18. Janowski M. Szkolnictwo zawodowe w Przemyślu pod okupacją niemiecką w latach $1940-1944 \mathrm{w}$ świetle zasobu Archiwum Państwowego w Przemyślu / M. Janowski // 2003. - T. 17. - S. 111-120.

19. Krasuski J. Tajne szkolnictwo polskie w okresie okupacji hitlerowskiej 1939 - 1945 / J. Krasuski. Wydanie drugie, rozszerone. - Warszawa: Państwowe Wydawnictwo Naukowe, 1977. - 411 s.

20. Król E. C. Polityka hitlerowska wobec szkolnictwa polskiego na terenie Generalnej guberni (1939 - 1945) / E. C. Król. - Warszawa: Wydawnictwa Szkolne i Pedagogiczne, 1979. - 243 s.

21. Majewski P. Wojna i kultura: instytucje kultury polskiej w okupacyjnych realiach Generalnego Gubernatorstwa 1939 - 1945 / R. Majewski. - Warszawa: Trio, 2005. - 431 s.

22. Matusak P. Edukacja i kultura Polski Podziemnej 1939 - 1945 / P. Matusak. - Siedlce, 1997. - 562 s.

23. Meducki S. Niemieckie okupacyjne szkolnictwo zawodowe w Generalnym Gubernatorstwie $1939-1945$ (na przykładzie dystryktu radomskiego) / Stanisław Meducki // Prace Naukowe Akademi i im. Jana Długosza w Częstochowie. Seria: Pedagogika. - 2012. - T. XXI. - S. 405-411.

24. Okupacja niemiecka cz. 3: Przemyśl w czasie II wojny światowej. - [Електронний ресурc]. - Режим доступу: http://wojnawp.republika.pl/niemcy/nn3.html

25. Opłaty w szkołach przysposobienia zawodowego // Gazeta Lwowska. Dziennik dla Dystryktu Galicyjskiego. - 1942. - Nr. 20. -24 stycznia. - S. 3.

26. Świeboda J. Zarys historii tajnej oświaty w latach ocupacji hitlerowskiej w powiecie przemyskim / J. Świeboda // Rocznik komisji nauk pedagogicznych PAN. - 1976. - T. XI: Materiały do dziejów oświaty w okresie ocupacji hitlerowskiej $(1939$ - 1945) na terenie podziemnego okręgu szkolnego krakowskiego. - Cz. X. - S. 183-193. Стаття надійшла до редакиії 22.10.2017 p. 